\title{
Repurposing of Dapsone as Neuroprotective Agent on Cuprizone-induced Demyelination via Targeting Nrf2 and NF-kB in C57BL/6 Mice
}

\section{Research Article}

Keywords:

Posted Date: May 14th, 2021

DOI: https://doi.org/10.21203/rs.3.rs-494322/v2

License: (c) (1) This work is licensed under a Creative Commons Attribution 4.0 International License. Read Full License 


\section{Abstract}

The authors have requested that this preprint be withdrawn due to erroneous posting.

\section{Full Text}

The authors have withdrawn this preprint from Research Square. 